\title{
Pengaruh Perlakuan Organomatrixpriming Terhadap Peningkatan Mutu Fisiologis Benih Cabai (Capsicum annuum L.)
}

\section{The Effect of Organomatrixpriming Treatment Toward Physiological Quality Enhancement of Pepper Seed (Capsicum annuum L.)}

\author{
Fatma Rosita Ratnaningtyas ${ }^{1}$ dan Endang Pudjihartati ${ }^{2 *}$ \\ ${ }^{1}$ Agroteknologi, Fakultas Pertanian dan Bisnis, Universitas Kristen Satya Wacana, Salatiga \\ ${ }^{2}$ Fakultas Pertanian dan Bisnis, Universitas Kristen Satya Wacana, Salatiga \\ *Email: endang.hartati@uksw.edu
}

Diterima 14 Desember 2018 / Disetujui 28 Januari 2019

\begin{abstract}
ABSTRAK
Penelitian ini bertujuan untuk mengetahui pengaruh organomatrixpriming dalam memperbaiki mutu fisiologis benih cabai. Benih yang digunakan adalah benih cabai varietas Ciko yang telah disimpan selama dua tahun dengan daya berkecambah 74,67\%. Penelitian ini menggunakan Rancangan Acak Kelompok (RAK) dengan faktor tunggal. Terdapat delapan perlakuan dan lima ulangan. Bahan organomatrixpriming yang diujikan adalah akuades, air kelapa, pupuk organik cair plus, tauge, tauge fermentasi, bonggol pisang, bonggol pisang fermentasi. Organomatrixpriming dilakukan menggunakan media zeolit selama 4 hari, kemudian dilanjutkan dengan pengujian perkecambahan menggunakan metode UKDdp. Hasil penelitian menunjukkan bahwa pemberian perlakuan pupuk organik cair plus dan bonggol pisang fermentasi dapat memperbaiki viabilitas benih cabai serta memenuhi standar daya berkecambah benih menurut Balitsa dan SNI yaitu $\geq 85 \%$. Tetapi organomatrixpriming yang lain tidak berpengaruh nyata terhadap peningkatan viabilitas dan vigor benih. Perlakuan tauge fermentasi justru menurunkan seluruh variabel mutu fisiologis. Infeksi Aspergillus yang menyebabkan benih busuk dan tumbuh abnormal saat pengujian perkecambahan paling tinggi terdapat pada perlakuan tauge.
\end{abstract}

Kata kunci : benih cabai, organomatrixpriming, viabilitas, vigor

\begin{abstract}
The purpose of this research is to examine the effect of organomatrixpriming to improve red pepper seed physiological quality. This research used red pepper seed var Ciko that had been stored for two years, germination percentage is 74,67\%. Research was arranged in experimental design using Random Group Design (RGD) with single factor. There are eight treatments and five repetitions. The materials for organomatrixpriming are aquadest, coconut water, liquid organic fertilizer, bean sprout extract, fermented of bean sprout extract, banana corm extract, and fermented banana corm extract. Seeds of red pepper were primed in zeolite for 4 days, and then the seeds were germinated on rice paper roll cover with plastic bag. The result of this research showed that organomatrixpriming using liquid organic fertilizer and fermented banana corm improved seed viability, and the percentage of normal seedling can appropriate with the Balitsa and SNI standards, which is $\geq 85 \%$. The effect of organomatrixpriming was not significant on seed viability and vigour test between all treatments. Organomatrixpriming treatment using fermented bean sprout tended to decrease seed physiological quality compared to the other treatment. Aspergillus infection causes rotten seeds and abnormal germination, the highest infection is on the fermented bean sprout extract treatment.
\end{abstract}

Keywords: pepper seed, organomatrixpriming, viability, vigour

\section{PENDAHULUAN}

Tanaman cabai merah (Capsicum annuum L.) merupakan salah satu jenis tanaman hortikultura yang banyak dibudidayakan di Indonesia dan merupakan salah satu produk hortikultura yang strategis. Cabai merah besar dibutuhkan dalam jumlah yang tinggi dan terus meningkat dari tahun 
2013-2017 (Setjen Departemen Pertanian, 2018) akan tetapi produksi dan produktivitasnya relatif tetap dan sedikit fluktuatif. Produksi dan Produktivitas cabai besar pada tahun 2013 s/d 2017 berturut-turut 1.012 .879 ton/tahun dan 8,16 ton/ha (2013), 1.072.977 ton/tahun dan 8,35 ton/ha (2014), 1.045.200 ton/tahun dan 8.65 ton/ha (2015), 1.045.591 ton/tahun dan 8,47 ton/ha (2016), serta menjadi sebesar 1206272 ton/tahun dan 8,46 ton/ha pada tahun 2017 (BPS 2015; BPS, 2018).

Salah satu usaha peningkatan produktivitas benih adalah dengan penggunaan benih bermutu. Benih bermutu perlu mendapatkan penanganan yang baik untuk menekan terjadinya deteriorasi benih. Benih yang telah mengalami deteriorasi perlu diberi perlakuan untuk merangsang metabolisme (Kuswanto, 2003). Salah satu upaya untuk meningatkan mutu benih yakni dengan perlakuan priming. Priming merupakan proses hidrasi benih secara terkontrol sehingga benih menyerap air namun tidak sampai berkecambah (Hossein, 2013). Metode tersebut juga dapat diperlukan oleh pemulia benih untuk menumbuhkan kembali koleksi benih yang biasanya disimpa dalam jangka waktu yang lama.

Salah satu jenis priming yang seringkali digunakan adalah matrixpriming yaitu dengan menempatkan benih dalam media padat yang lembab (Widajati et al., 1990). Media padatan yang dapat digunakan dalam matrixpriming adalah zeolit. Zeolit sering disebut sebagai agen penyedia lambat (slow release agent) karena kemampuan pertukaran kationnya yang tinggi, mengikat dan menyimpan air atau pupuk. Zeolit hanya sebagai pembawa dalam pelepasan air dan hara bagi tanaman (Suwardi, 2009).

Perlakuan matrixpriming dapat dilakukan dengan menambahkan bahan-bahan tertentu yang dapat membantu meningkatkan perkecambahan benih. Beberapa bahan yang dapat digunakan sebagai campuran adalah bahan nabati yang mengandung zat pengatur tumbuh, seperti air kelapa muda, tauge, bonggol pisang, dan pupuk organik cair yang digunakan pada penelitian ini. Perlakuan priming dengan penambahan bahan nabati ini disebut organomatrixpriming. Diharapkan nutrisi yang terdapat pada bahan bahan nabati dapat meningkatkan mutu benih cabai yang telah disimpan selama dua tahun. Oleh karena itu, penelitian ini dilakukan dengan tujuan untuk mengetahui pengaruh perlakuan organomatrixpriming dalam memperbaiki mutu fisiologis benih cabai varietas Ciko yang telah mengalami kemunduran.

\section{METODE PENELITIAN}

\section{Matrixpriming}

Benih cabai yang diteliti adalah benih cabai besar varietas Ciko yang diperoleh dari Balai Penelitian Tanaman Sayuran, Lembang, Jawa Barat. Benih cabai tersebut telah disimpan selama dua tahun. Metode penelitian yang digunakan adalah Rancangan Acak Kelompok (RAK) dengan satu faktor yaitu berbagai bahan organik dalam matrixpriming. Penelitian ini terdapat delapan perlakuan dan lima kali pengulangan. Perlakuan yang diujikan antara lain:

1. Kontrol (Benih kering)

2. Matrixpriming dengan akuades

3. Organomatrixpriming dengan air kelapa muda

4. Organomatrixpriming dengan pupuk organik cair plus

5. Organomatrixpriming dengan ekstrak tauge segar

6. Organomatrixpriming dengan ekstrak tauge fermentasi

7. Organomatrixpriming dengan ekstrak bonggol pisang segar

8. Organomatrixpriming dengan ekstrak bonggol pisang fermentasi

\section{Penetapan Perbandingan Benih, Media Padat, dan Cairan}

Pada penelitian ini, masing-masing cairan yang akan digunakan melalui proses yang berbeda beda sebelum diaplikasikan pada media zeolit saat priming. Air kelapa dicampur dengan akuades hingga mencapai konsentrasi 50\%. Pupuk organik cair plus dilarutkan dengan akuades, $1 \mathrm{ml}$ pupuk cair per $200 \mathrm{ml}$ akuades. Pembuatan ekstrak pada perlakuan 5 (tauge segar) dan 7 (bonggol pisang segar) dilakukan dengan menghaluskan sebanyak 20 gram bahan utama dan $100 \mathrm{ml}$ akuades, kemudian dipisahkan dari ampasnya. Pada 
perlakuan 6 (tauge fermentasi) dan 8 (bonggol pisang fermentasi), cairan dibuat dengan cara mencampurkan sebanyak 200 gram bahan utama yang telah dihaluskan, 1 liter akuades, 200 gram gula, dan $50 \mathrm{ml}$ EM4. Fermentasi dilakukan selama 14 x 24 jam. Perlakuan matrixpriming dilakukan dengan memeram benih cabai di dalam media matrixpriming berupa zeolit. Zeolit yang digunakan berukuran $\pm 1 \mathrm{~mm}$.Zeolit steril dicampur dengan cairan sesuai perlakuan hingga lembab. Matrixpriming benih dilakukan selama 4 x 24 jam, kemudian dilakukan pengujian perkecambahan. Perbandingan antara benih, zeolit dan cairan disajikan pada Tabel 1.

Tabel 1. Perbandingan antara benih, zeolit dan cairan bahan organik

\begin{tabular}{lc}
\hline \multicolumn{1}{c}{ Perlakuan } & $\begin{array}{c}\text { Perbandingan } \\
\text { Benih : } \text { Zeolit : Cairan }(\mathbf{b} / \mathbf{b} / \mathbf{v})\end{array}$ \\
\hline Kontrol & Benih kering \\
Akuades & $1 ; 30 ; 4$ \\
Air Kelapa & $1 ; 30 ; 4$ \\
Pupuk Organik Cair Plus & $1 ; 30 ; 4$ \\
Tauge & $1 ; 30 ; 4$ \\
Tauge Fermentasi & $1 ; 30 ; 7$ \\
Bonggol Pisang & $1 ; 30 ; 4$ \\
Bonggol Pisang Fermentasi & $1 ; 30 ; 7$ \\
\hline
\end{tabular}

\section{Pembuatan Ekstrak Tauge dan Bonggol Pisang}

Pembuatan ekstrak tauge dan bonggol pisang dilakukan dengan mencampurkan tauge atau bonggol pisang ke dalam akuades. Kemudian dihaluskan dan hasilnya disaring menggunakan kertas saring sebelum digunakan untuk melembabkan zeolit.

\section{Fermentasi Tauge dan Bonggol Pisang}

Tauge atau bonggol pisang, gula, dan akuades dihaluskan dengan menggunakan. Kemudian ditambahkan EM4, dan difermentasi selama 14 hari dalam keadaan anaerob. Setelah 14 hari, hasil ekstrak tauge dan bonggol pisang disaring menggunakan kertas saring untuk memisahkan cairan dengan ampas.

\section{Pengujian Viabilitas dan Vigor Benih}

Pengujian perkecambahan dilakukan dengan metode Uji Kertas Digulung didirikan dimasukkan dalam plastik (UKDdp). Pengamatan yang dilakukan dalam penelitian ini adalah:

1. Daya Berkecambah (DB) Jumlah kecambah normal yang tumbuh Jumlah contoh benih yang diuji
2. Kecepatan Tumbuh $\left(\mathrm{K}_{\mathrm{CT}}\right)$

$$
\begin{aligned}
\mathrm{K}_{\mathrm{CT}}(\% / \mathrm{etmal})= & \sum \frac{\mathrm{N}}{\mathrm{t}}=\frac{\% \mathrm{KN} 1}{\mathrm{t} 1}+\frac{\% \mathrm{KN} 2}{\mathrm{t} 2}+\frac{\% \mathrm{KN} 3}{\mathrm{t} 3} \\
& +\ldots+\frac{\% \mathrm{KNy}}{\mathrm{ty}}
\end{aligned}
$$

3. Keserempakan Tumbuh $\left(\mathrm{K}_{\mathrm{ST}}\right)$

$$
\mathrm{K}_{\mathrm{ST}}(\%)=\frac{\text { Jumlah KNH1 vigor }}{\text { Jumlah benih yang dikecambahkan }} \times 100 \%
$$

4. Pertumbuhan Kecambah

Parameter pertumbuhan kecambah meliputi panjang akar, tinggi, dan bobot kering kecambah normal pada akhir periode pengamatan (hari ke-14).

Untuk mengetahui pengaruh pemberian berbagai perlakuan, dilakukan analisis datadengan sidik ragam dan BNJ pada taraf kepercayaan $95 \%$. Pada uji perkecambahan juga diamati kecambah abnormal dan benih mati atau busuk akibat infeksi Aspergillus.

\section{HASIL DAN PEMBAHASAN}

\section{Viabilitas dan Vigor Benih}

Viabilitas benih merupakan kemampuan benih untuk tumbuh normal pada keadaan lingkungan tumbuh yang optimal (Sadjad, 1993). Viabilitas benih berkaitan dengan mutu fisiologis benih. Mutu fisiologis akan maksimal saat 
mencapai kematangan fisiologis, dan akan mengalami deteriorasi selama penyimpanan. Pada penelitian ini, viabilitas benih diamati melalui daya berkecambah benih kontrol (benih kering) dan benih dengan perlakuan matrixpriming. Hasil pengamatan pada Gambar 1 menunjukkan bahwa dibanding dengan kontrol benih kering ( $\mathrm{POKN})$, perlakuan akuades (P1AQ) menurunkan persen benih busuk/mati, meningkatkan persen total benih berkecambah karena persen kecambah abnormal meningkat namun persen kecambah normal sedikit menurun. Hal ini menunjukkan perlakuan akuades mampu mengurangi benih busuk/mati karena mampu berkecambah meskipun abnormal.

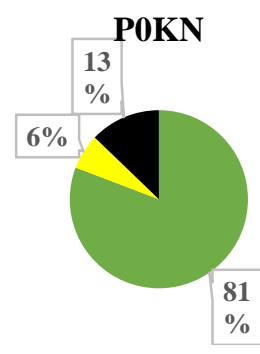

P4TA

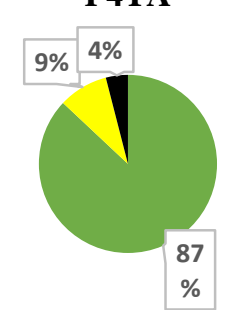

P1AQ

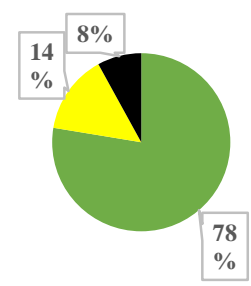

P5TF

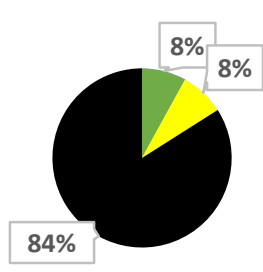

P2AK

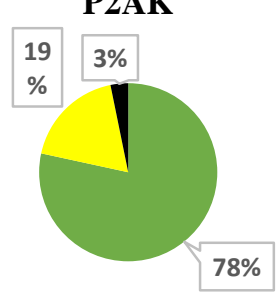

P6BP

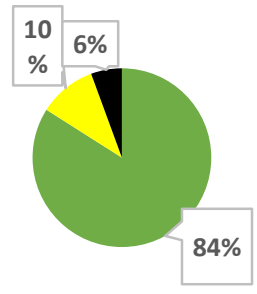

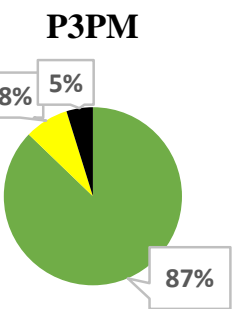

P7BF

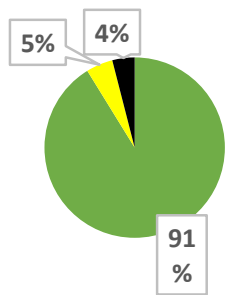

Gambar 1. Diagram lingkaran persentase komponen uji viabilitas dan vigor benih

Keterangan :

: Kecambah normal

POKN : Kontrol

P1AQ : Akuades

P2AK : Air Kelapa

P3PM : Pupuk Organik Cair Plus
: Kecambah abnormal

P4TA : Tauge

P5TF : Tauge Fermentasi

P6BP : Bonggol Pisang

P7BF : Bonggol Pisang Fermentasi
Perlakuan air kelapa (P2AK) dapat menurunkan persentase benih busuk/mati dibanding kontrol benih kering (P0KN) dan akuades (P1AQ). Perlakuan P3PM, P4TA, P6BP dapat meningkatkan kecambah normal dibanding kontrol dan akuades. Benih lebih mampu untuk berkecambah walaupun belum mampu tumbuh normal. Akan tetapi, jumlah benih yang mampu tumbuh menjadi kecambah normal meningkat. Perlakuan tauge fermentasi (P5TF) menyebabkan persentase benih busuk/mati tertinggi, dan persentase kecambah normal terendah (Gambar 4). Benih busuk pada perlakuan tauge fermentasi disebabkan tumbuhnya cendawan dan bakteri. Selain itu terdapat terdapat patogen lain berupa bakteri yang menyebabkan benih busuk berlendir dan bagian dalam benih menghitam. Perlakuan bonggol pisang fermentasi (P7BF) dapat menurunkan persentase benih busuk dan kecambah abnormal dibanding perlakuan akuades. Selain itu, jumlah kecambah normal perlakuan P7BF meningkat (Gambar 3) dibanding perlakuan kontrol (Gambar 2), akuades, dan seluruh perlakuan organomatrixpriming.

Hasil penelitian (Tabel 2) menunjukkan bahwa daya berkecambah perlakuan matrixpriming dengan akuades (P1AQ) belum mampu meningkatkan daya berkecambah dibanding kontrol (P0KN). Diduga karena akuades dapat lebih cepat terserap oleh benih. Yullianida (2005) dalam 
penelitiannya mengenai invigorasi benih bunga matahari menyatakan bahwa aktivitas metabolisme benih yang tinggi selama proses imbibisi memungkinkan terkurasnya energi sehingga saat proses awal perkecambahan benih kekurangan energi..

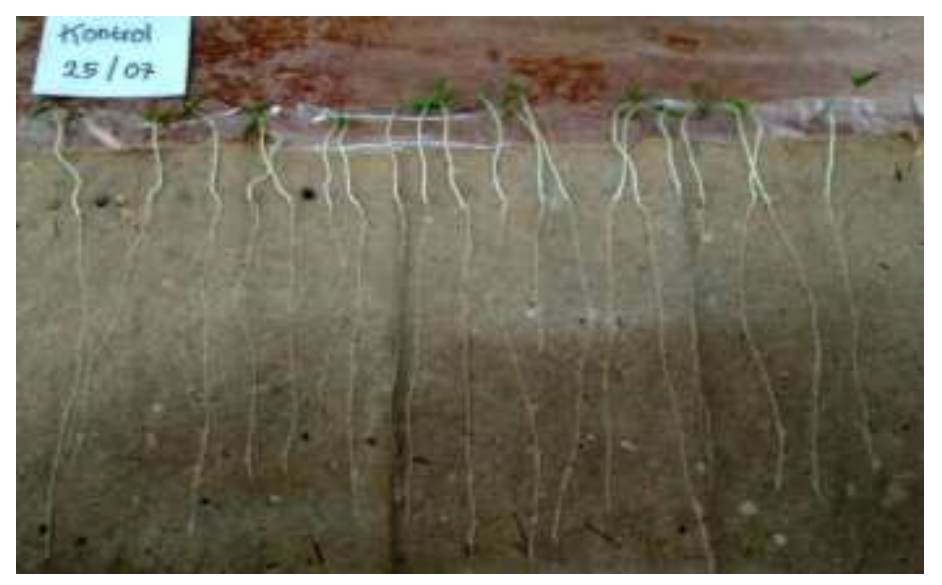

Gambar 2. Kecambah perlakuan Kontrol (P0KN) pada akhir periode pengamatan.

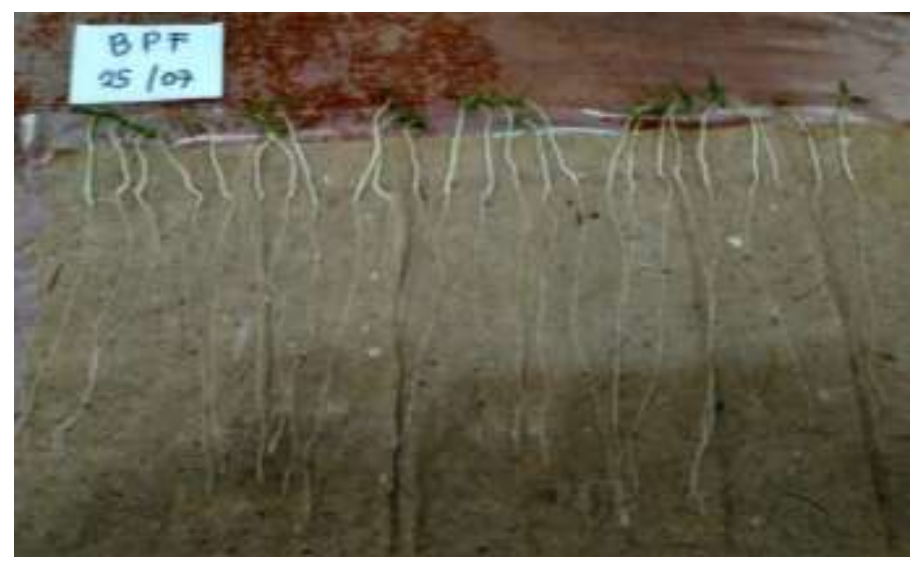

Gambar 3. Kecambah perlakuan bonggol pisang fermentasi (P7BF) pada akhir periode pengamatan.

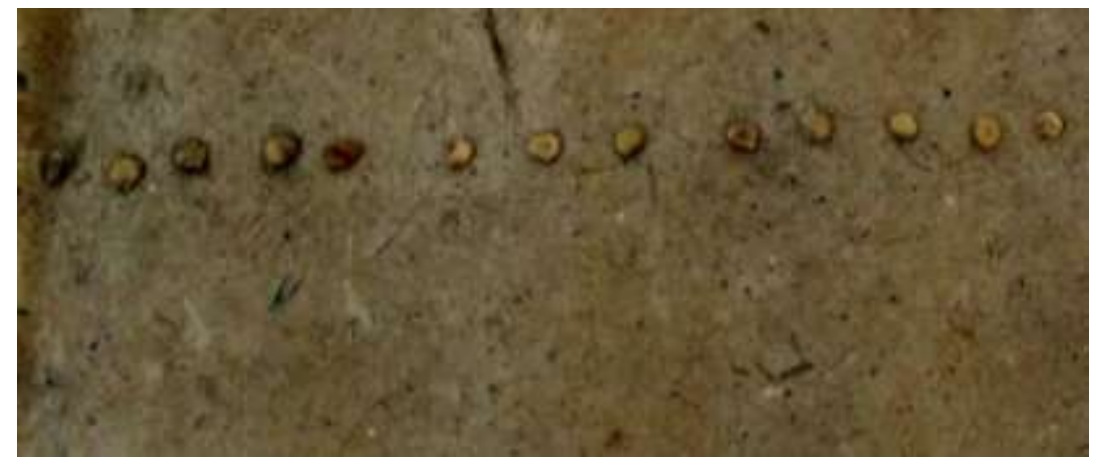

Gambar 4. Benih perlakuan tauge fermentasi (P5TF) mengalami kebusukan.

Pemberian perlakuan air kelapa (P2AK) belum mampu meningkatkan daya berkecambah dibanding perlakuan P1AQ. Hal tersebut diduga dikarenakan jika nutrisi yang terkandung di dalam air kelapa konsentrasinya tidak tepat, dapat memacu perkecambahan atau sebaliknya dapat menghambat perkecambahan. Pada penelitian ini, air kelapa diberikan dalam perbandingan benih : zeolit : air 
kelapa sebanyak 1 : $30: 4$ dengan konsentrasi 50\%. Hasil penelitian yang dilakukan Halimursyadah dkk (2015) menunjukkan bahwa hydropriming benih cabai menggunakan air kelapa muda dapat memperbaiki daya berkecambah benih ketika di priming dengan konsentrasi $15 \%$ selama 72 jam. Menurut Suryanto (2009), di dalam air kelapa terkandung mineral dan zat pengatur tumbuh berupa auksin dan sitokinin. Krisantini (2011) menambahkan, terdapat pula giberelin pada air kelapa. Menurut Gardner et al (1991), sitokinin dan giberelin merupakan zat pengatur tumbuh yang dapat membantu proses perkecambahan benih. Akan tetapi Kuswanto (2003) menambahkan bahwa auksin merupakan salah satu zat yang memiliki sifat menghambat metabolisme benih yang kemudian diikuti dengan terhambatnya proses perkecambahan.
Balitsa memiliki ketentuan daya berkecambah minimal bagi benih dasar cabai(Waluyo, 2016), demikian pula standar yang ditetapkan oleh SNI 01-7005-2004 bagi benih cabai hibrida, yaitu $\geq 85 \%$. Pada penelitian ini, benih cabai yang diberi perlakuan P3PM dan P7BF dapat memenuhi standar Balitsa dan SNI.

Berdasarkan analisis statistika, pemberian perlakuan P3PM mampu meningkatkan daya berkecambah benih meskipun tidak berbeda nyata dengan perlakuan P1AQ. Hal tersebut berkaitan dengan pengaruh dari priming dengan bahan organik yang dapat mempengaruhi metabolisme benih sehingga dapat memberikan kesempatan bagi benih untuk persiapan memasuki proses perkecambahan. Persentase benih busuk dapat menurun dan jumlah benih berkecambah normal dapat meningkat.

Tabel 2. Viabilitas dan vigor benih cabai

\begin{tabular}{lccc}
\hline \multicolumn{1}{c}{ PERLAKUAN } & DB $(\boldsymbol{\%})$ & $\begin{array}{c}\text { VK }_{\mathbf{C T}} \\
(\boldsymbol{\%} / \mathbf{e t m a l})\end{array}$ & VK $_{\text {ST }}(\boldsymbol{\%})$ \\
\hline Kontrol (POKN) & $80.80^{\mathrm{ab}}$ & $11.25^{\mathrm{a}}$ & $8.00^{\mathrm{ab}}$ \\
Akuades (P1AQ) & $77.60^{\mathrm{b}}$ & $11.66^{\mathrm{a}}$ & $12.00^{\mathrm{ab}}$ \\
Air Kelapa (P2AK) & $78.40^{\mathrm{b}}$ & $11.92^{\mathrm{a}}$ & $16.00^{\mathrm{a}}$ \\
Pupuk Organik Cair Plus (P3PM) & $87.20^{\mathrm{ab}}$ & $12.63^{\mathrm{a}}$ & $14.40^{\mathrm{a}}$ \\
Tauge (P4TA) & $78.40^{\mathrm{ab}}$ & $12.05^{\mathrm{a}}$ & $12.00^{\mathrm{ab}}$ \\
Tauge Fermentasi (P5TF) & $8.00^{\mathrm{c}}$ & $0.63^{\mathrm{b}}$ & $0.00^{\mathrm{b}}$ \\
Bonggol Pisang (P6BP) & $84.00^{\mathrm{ab}}$ & $13.69^{\mathrm{a}}$ & $18.40^{\mathrm{a}}$ \\
Bonggol Pisang Fermentasi (P7BF) & $91.20^{\mathrm{a}}$ & $12.12^{\mathrm{a}}$ & $8.00^{\mathrm{ab}}$ \\
\hline
\end{tabular}

Keterangan: Angka yang diikuti superskrip yang sama pada baris yang sama menunjukkan hasil yang tidak berbeda nyata $(\mathrm{P}>0,05)$ pada taraf signifikansi $5 \%$. DB : daya berkecambah benih (\%), VKCT : vigor kecepatan tumbuh benih (\%/etmal), VKST : vigor keserempakan tumbuh benih (\%).

Perlakuan P3PM mengandung

mikroorganisme menguntungkan, serta unsur hara makro dan mikro. Menurut Anonim (2016), pupuk organik cair PM mengandung mikroorganisme yang berperan dalam menstimulasi zat pengatur tumbuh. Selain itu terdapat pula unsur hara makro $(\mathrm{N}, \mathrm{P}, \mathrm{K}, \mathrm{Ca}$, dan $\mathrm{Mg}$ ) serta unsur hara mikro (B, $\mathrm{Cu}, \mathrm{Fe}$, dan $\mathrm{Mo}$ ). Menurut Salisbury dan Ross (1995), unsur hara nitrogen $(\mathrm{N})$ akan diperlukan benih sebagai penyusun badan protein. Timotiwu dan Nurmauli (1996) menambahkan Fosfor (P) merupakan sel hidup, selain itu juga penyusun fosfolipid, nukleoprotein, serta fitin yang terdapat dalam benih. Pada penelitiannya, Supriyanto dkk (2012) menyatakan bahwa Boron merupakan unsur penting yang dibutuhkan dalam perkecambahan. Secara tidak langsung, Boron berperan dalam meningkatkan daya berkecambah dan kecepatan tumbuh benih cendana.

Perlakuan tauge (P4TA) meningkatkan perkecambahan benih cabai meskipun tidak nyata dibanding perlakuan akuades. Hal tersebut diduga karena pada tauge tidak hanya mengandung vitamin $\mathrm{C}$ saja, akan tetapi juga mengandung vitamin $\mathrm{A}$ dan B (Amilah dan Astuti, 2006). Vitamin A, B2, C dan E merupakan komponen antioksidan alami yang 
secara umum dapat mengontrol proses oksidasi lipid (Sayuti dan Yenrina, 2015).

Perlakuan P5TF menurunkan daya berkecambah secara nyata dibanding kontrol dan perlakuan yang lain. Rendahnya viabilitas benih pada perlakuan P5TF, diduga disebabkan oleh adanya kandungan etanol sebagai hasil dari proses fermentasi ekstrak tauge. Pada saat dilakukan pengamatan, ekstrak tauge memiliki bau etanol yang kuat. Menurut Amanah dkk. (2016), etanol yang masuk ke dalam benih dapat menyebabkan kerusakan protein sebagai komponen yang penting pada benih.

Berbeda dengan perlakuan P5TF, perlakuan bonggol pisang fermentasi (P7BF) justru mampu meningkatkan daya berkecambah benih hingga 91\% sehingga memenuhi ketentuan daya berkecambah minimal sebagai benih dasar menurut Balitsa serta memenuhi standar SNI yakni $\geq 85 \%$. Meskipun difermentasi dengan perbandingan bahan utama, akuades, gula dan $\mathrm{EM}_{4}$ yang sama, kandungan karbohidrat pada bonggol pisang berbeda dengan tauge.

Pada perlakuan P7BF, daya berkecambah benih meningkat meskipun tidak berbeda nyata dengan P6BP. Hal tersebut diduga dapat disebabkan oleh adanya zat pengatur tumbuh yang secara alami terdapat pada bonggol pisang. Menurut Maspary (2012) menyatakan bahwa zat pengatur tumbuh yang terkandung dalam bonggol pisang yaitu sitokinin dan giberelin. Setelah melalui proses fermentasi pada perlakuan P7BF, dihasilkan zat pengatur tumbuh yang diduga dapat membantu meningkatkan daya berkecambah benih. Lindung (2014), melakukan fermentasi pada bonggol pisang dapat membantu menghasilkan zat pengatur tumbuh. Gardner et al (1991) menyatakan bahwa zat pengatur tumbuh sitokinin dan giberelin dapat membantu proses perkecambahan benih.

Pada saat pengujian perkecambahan, ditemukan cendawan dari genus Aspergillus pada permukaan benih dan pangkal radikula. Infeksi Aspergillus menyebabkan beberapa benih tumbuh menjadi kecambah abnormal, bahkan mengalami kebusukan (Gambar 5 dan 6).

Perlakuan matrixpriming dengan akuades dan bahan organik belum mampu mengurangi infeksi Aspergillus pada benih cabai (Tabel 3).
Akan tetapi pada perlakuan pupuk organik cair plus (P3PM), tauge fermentasi (P5TF), dan bonggol pisang fermentasi (P7BF) memiliki kecenderungan untuk menurunkan infeksi Aspergillus meskipun tidak nyata dibandingkan dengan perlakuan lain. Pupuk organik cair plus mengandung beberapa mikroorganisme yang diduga dapat menghasilkan antibiotik seperti Bacillus (Anonimb, 2016). Pada saat penelitian diamati perlakuan tauge fermentasi dan bonggol pisang fermentasi memiliki aroma alkohol yang kuat. Hal tersebut dapat mempengaruhi perkembangan Aspergillus.

Perlakuan tauge (P4TA) memiliki persentase total infeksi paling tinggi meskipun tidak nyata dibandingkan matrixpriming akuades (Tabel 3). Hal tersebut diduga karena tauge memiliki nutrisi dalam jumlah tertentu yang diperlukan untuk perkembangan Aspergillus. Pada tauge mengandung karbohidrat dalam bentuk sederhana, protein, vitamin dan unsur hara dalam jumlah tertentu (Gandjar dkk., 2006).

Nilai vigor benih diamati dari nilai kecepatan tumbuh benih $\left(\mathrm{VK}_{\mathrm{CT}}\right)$ dan keserempakan tumbuh benih $\left(\mathrm{VK}_{\mathrm{ST}}\right)$ seperti disajikan pada Tabel 2. $\mathrm{K}_{\mathrm{CT}}$ diketahui berdasarkan jumlah pertambahan kecambah normal setiap harinya selama pengujian perkecambahan. Pada penelitian ini, pemberian perlakuan organomatrixpriming dengan menggunakan P2AK, P3PM, P4TA, P6BP, dan P7BF memiliki kecepatan tumbuh yang tidak berbeda secara statistik apabila dibandingkan dengan kontrol akuades (POAQ).

Nilai keserempakan tumbuh $\left(\mathrm{K}_{\mathrm{ST}}\right)$ diperoleh dari jumlah kecambah normal vigor dalam kondisi optimal di hari ke-7 $\left(\mathrm{KH}_{1}\right)$. Hasil analisis statistik menunjukkan bahwa perlakuan matrixpriming dengan akuades (P1AQ) belum mampu mempengaruhi keserempakan tumbuh benih cabai apabila dibandingkan dengan kontrol (POKN). Akan tetapi secara nominal, nilainya mampu ditingkatkan.

Kecepatan dan keserempakan tumbuh benih pada perlakuan tauge fermentasi (P5TF) cenderung menurun (Tabel 2). Hal tersebut diduga karena pada perlakuan tersebut terdapat kandungan etanol yang tinggi yang merusak benih, sehingga mempengaruhi proses perkecambahan benih dan kemampuan benih untuk dapat tumbuh normal 
setiap harinya. Hal tersebut juga didukung oleh daya berkecambah benih perlakuan P5TF yang secara nyata menurun apabila dibandingkan dengan perlakuan lain.

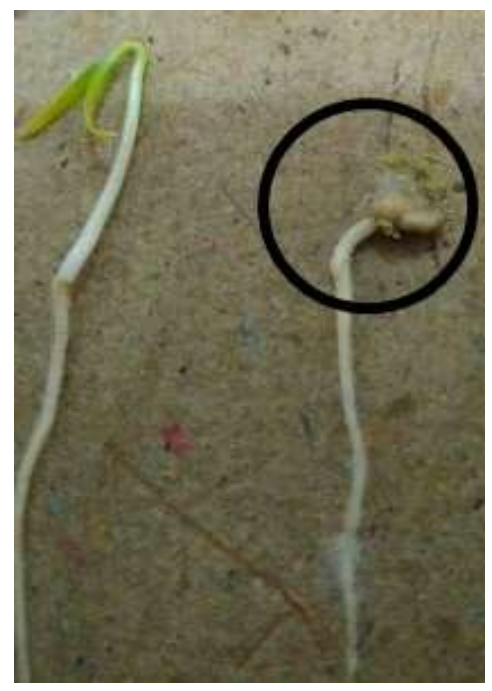

Gambar 5. Kecambah abnormal akibat infeksi Aspergillus

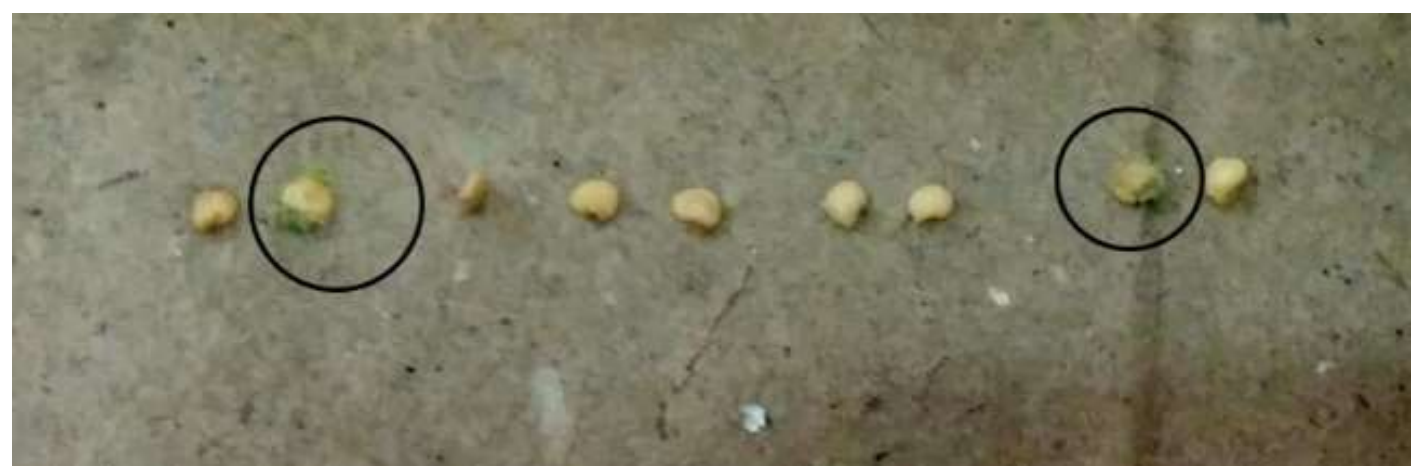

Gambar 6. Infeksi Aspergillus pada permukaan benih

\section{Pertumbuhan Kecambah}

Pada penelitian ini, pertumbuhan kecambah yang diamati antara lain panjang akar, tinggi kecambah, dan berat kering kecambah normal. Berdasarkan analisis data (Tabel 4), tidak ada perbedaan nyata antar perlakuan kecuali perlakuan P5TF karena perlakuan yang dicobakan belum mampu mempengaruhi pertumbuhan akar secara langsung. Akan tetapi dapat dipengaruhi oleh ketersediaan air selama proses perkecambahan.

Parameter pengamatan tinggi kecambah antar perlakuan tidak berbeda. Pada perlakuan tauge fermentasi justru menurun secara nyata. Hal tersebut dapat berkaitan dengan kecepatan tumbuh benih yang juga tidak berbeda nyata antar perlakuan, kecuali perlakuan tauge fermentasi.
Benih yang cepat berkecambah berarti lebih dahulu mengalami pertumbuhan. Sehingga pada akhir periode pengamatan yang sama, benih yang cepat berkecambah akan lebih tinggi.

Berat berangkasan kering (BBK) kecambah menunjukkan asimilat yang terdapat dalam kecambah pada benih cabai dan efisiensi pemanfaatan cadangan makanan pada benih (Gardner, 1991; Barlian dkk., 1998). Pada Tabel 4, berat berangkasan kering kecambahtidak berbeda antar perlakuan, bahkan perlakuan tauge fermentasi lebih rendah dibandingkan perlakuan lain. Hal tersebut disebabkan oleh perlakuan organomatrixpriming dengan tauge fermentasi yang dilakukan dalam penelitian ini Nurussintani dkk. (2013) menyatakan bahwa vigor benih dapat diketahui melalui bobot kering kecambah normal. 
Benih yang memiliki vigor tinggi akan mampu membentuk serta mentranslokasikan cadangan makanan dengan cepat.

Tabel 3. Infeksi Aspergillus saat uji perkecambahan

\begin{tabular}{lccc}
\hline \multicolumn{1}{c}{ Perlakuan } & $\begin{array}{c}\text { Kecambah Abnormal } \\
(\boldsymbol{\%})\end{array}$ & $\begin{array}{c}\text { Benih Busuk } \\
(\boldsymbol{\%})\end{array}$ & Total Infeksi \\
\hline Kontrol (P0KN) & $5,60^{\mathrm{ab}}$ & $4,80^{\mathrm{ab}}$ & $10,4^{\mathrm{ab}}$ \\
Akuades (P1AQ) & $6,00^{\mathrm{ab}}$ & $8,00^{\mathrm{b}}$ & $14,0^{\mathrm{ab}}$ \\
Air Kelapa (P2AK) & $12,00^{\mathrm{b}}$ & $3,20^{\mathrm{ab}}$ & $15,2^{\mathrm{ab}}$ \\
Pupuk Organik Cair Plus (P3PM) & $1,00^{\mathrm{a}}$ & $4,00^{\mathrm{ab}}$ & $5,0^{\mathrm{a}}$ \\
Tauge (P4TA) & $19,20^{\mathrm{b}}$ & $3,20^{\mathrm{ab}}$ & $22,4^{\mathrm{b}}$ \\
Tauge Fermentasi (P5TF) & $0,00^{\mathrm{a}}$ & $0,00^{\mathrm{a}}$ & $0,0^{\mathrm{a}}$ \\
Bonggol Pisang (P6BP) & $13,60^{\mathrm{b}}$ & $4,00^{\mathrm{ab}}$ & $17,6^{\mathrm{ab}}$ \\
Bonggol Pisang Fermentasi (P7BF) & $0,00^{\mathrm{a}}$ & $3,20^{\mathrm{ab}}$ & $3,2^{\mathrm{a}}$ \\
\hline
\end{tabular}

Keterangan:

Angka yang diikuti superskrip yang sama pada baris yang sama menunjukkan hasil yang tidak berbeda nyata $(\mathrm{P}>0,05)$ pada taraf signifikansi $5 \%$.

Tabel 4. Pertumbuhan kecambah pada berbagai perlakuan

\begin{tabular}{lccccc}
\hline \multicolumn{1}{c}{ PERLAKUAN } & \multirow{2}{*}{ PA $(\mathbf{c m})$} & \multirow{2}{*}{ TT $(\mathbf{c m})$} & \multicolumn{2}{c}{ BBK $(\mathbf{m g})$} & TOTAL \\
& & & AKAR & PUCUK & BBK $(\mathbf{m g})$ \\
\hline Kontrol (P0KN) & $10.51^{\mathrm{a}}$ & $3.98^{\mathrm{a}}$ & $1.43^{\mathrm{a}}$ & $1.62^{\mathrm{a}}$ & $3.05^{\mathrm{a}}$ \\
Akuades (P1AQ) & $10.26^{\mathrm{a}}$ & $3.96^{\mathrm{a}}$ & $1.26^{\mathrm{ab}}$ & $1.76^{\mathrm{a}}$ & $3.01^{\mathrm{a}}$ \\
Air Kelapa (P2AK) & $10.02^{\mathrm{a}}$ & $3.85^{\mathrm{a}}$ & $1.15^{\mathrm{ab}}$ & $1.66^{\mathrm{a}}$ & $2.81^{\mathrm{a}}$ \\
Pupuk Organik Cair Plus (P3PM) & $10.53^{\mathrm{a}}$ & $3.87^{\mathrm{a}}$ & $1.31^{\mathrm{a}}$ & $1.63^{\mathrm{a}}$ & $2.94^{\mathrm{a}}$ \\
Tauge (P4TA) & $10.57^{\mathrm{a}}$ & $4.08^{\mathrm{a}}$ & $1.21^{\mathrm{ab}}$ & $1.82^{\mathrm{a}}$ & $3.03^{\mathrm{a}}$ \\
Tauge Fermentasi (P5TF) & $3.13^{\mathrm{b}}$ & $1.13^{\mathrm{b}}$ & $0.56^{\mathrm{b}}$ & $0.78^{\mathrm{b}}$ & $1.34^{\mathrm{b}}$ \\
Bonggol Pisang (P6BP) & $10.33^{\mathrm{a}}$ & $4.09^{\mathrm{a}}$ & $1.21^{\mathrm{ab}}$ & $1.73^{\mathrm{a}}$ & $2.94^{\mathrm{a}}$ \\
Bonggol Pisang Fermentasi (P7BF) & $10.84^{\mathrm{a}}$ & $3.95^{\mathrm{a}}$ & $1.3^{\mathrm{ab}}$ & $1.77^{\mathrm{a}}$ & $3.07^{\mathrm{a}}$ \\
\hline
\end{tabular}

Keterangan:

Angka yang diikuti superskrip yang sama pada baris yang sama menunjukkan hasil yang tidak berbeda nyata $(\mathrm{P}>0,05)$ pada taraf signifikansi 5\%. PA : panjang akar, TT : tinggi tanaman, BBK : berat berangkasan kering

\section{KESIMPULAN}

Benih cabai dengan perlakuan organomatrixpriming menggunakan pupuk organik cair plus (P3PM), dan bonggol pisang fermentasi (P7BF) meningkatkan daya berkecambah meskipun tidak nyata. Vigor benih yakni pertumbuhan kecambah belum dapat ditingkatkan. Perlakuan tauge fermentasi (P5TF) cenderung menurunkan nilai viabilitas, vigor, dan pertumbuhan kecambah. Benih cabai dengan perlakuan pupuk organik cair plus (P3PM) dan bonggol pisang fermentasi (P7BF) mampu memenuhi standar menurut SNI dan standar daya berkecambah benih dasar menurut Balitsa dan yakni $\geq 85 \%$.Infeksi Aspergillus yang menyebabkan benih busuk dan tumbuh abnormal saat pengujian perkecambahan paling tinggi terdapat pada perlakuan tauge.

\section{DAFTAR PUSTAKA}


Amilah dan Astuti. 2016. Pengaruh Konsentrasi Ekstrak Tauge dan Kacang Hijau Pada media Vacin and Went (VW) Terhadap pertumbuhan Kecambah Anggrek Bulan (Phalaenopsis amabilis L.). Bulletin Penelitian 9: 78-96.

Badan Pusat Statistik. 2015. Katalog Statistik Tanaman Sayuran dan Buah-buahan Semusim Indonesia 2014.

Badan Pusat Statistik. 2018. Katalog Statistik Tanaman Sayuran dan Buah-buahan Semusim Indonesia 2017.

Barlian, J., Yeni, H. dan Masano. 1998. Studi Fenolohi dan Pengaruh Posisi Buah Serta Ukuran Benih Terhadap Viabilitas Benih Gmelina (Gmelina arborea Roxb). BulletinAgronomi 26(2): 8-12.

Gardner, F. P., R. B. Pearce dan R.L Mitchell. 1991. Fisiologi Tanaman Budidaya. Universitas Indonesia Press. Jakarta.

Hossein, S. 2013. Effect of Seed Priming on Germination and Yield of Corn. International Journal of Agriculture and Crop Science 5 (4): 366-369.

Kuswanto, H. 2003. Dasar-Dasar Teknologi, Produksi dan Sertifikasi Benih. Penerbit Andi. Yogyakarta.

Krisantini dan Tija, B.O. 2011. Panduan Penggunaan dan Aplikasi Zat Pengatur Tumbuh Pada Tanaman Hias. Departemen Hortikultura. Fakultas Pertanian. Institut Pertanian Bogor.

Lindung. 2014. Teknologi Aplikasi Zat Pengatur Tumbuh(ZPT: Plant Growth Regulator).http://www.bppjambi.info/?v=new $s \& i d=589$. Diakses pada tanggal 4 November 2016. Pukul 18.30 WIB.

Nurussintani, W. D. dan Purnamaningsih. 2013. Perlakuan pematahan dormansi terhadap daya tumbuh benih tiga varietas kacang tanah (Arachis hypogeaea). Jurn. Produksi Tanaman 1(1): $86-93$.

Sadjad, S. 1993. Dari Benih Kepada Benih. PT Gramedia Widiasarana Indonesia. Jakarta.
Sayuti, K dan Yenrina, R. 2015. Antioksidan Alami dan Sintetik. Andalas University Press. Padang.

Suprianto, A.S.M., dan Subandi, B. 2012. Pengaruh boron dan perendaman terhadap perkecambahan benih cendana (Santalum album Linn). Jurn. Silvikultur Tropika 3(3): $182-186$.

Suwardi. 2009. Teknik aplikasi zeolite di bidang pertanian sebagai bahan pembenah tanah. Jurn. Zeolit Indonesia 8(1): 33 - 38.

Waluyo, N. 2016. Persyaratan Teknis Minimal (PTM) Mutu Fisik Benih Beberapa Komoditas Sayuran. Kelti Pemuliaan Perbenihan dan Plasma Nutfah. Balai Penelitian Tanaman Sayuran.

Widajati, E., Suwarno, F.C. dan Murniati. 1990. Pengaruh perlakuan "priming" terhadap vigor bibit kacang tanah. Jurn. Keluarga Benih 1(1): 14-20.

Yullianida, E. M. 2005. Pengaruh antioksidan sebagai perlakuan invigorasi benih sebelum simpan terhadap daya simpan benih bunga matahari (Helianthus annuиs L.). Hayati Journal of Biosciences 12: 145 - 150. 